\title{
HÁROM KOSSUTH-DÍJAS BAJAI ÉPÍTÉSZ
}

\author{
MEZÖS TAMÁS \\ CSc, DLA, egyetemi tanár. BME Építészettörténeti és Müemléki Tanszék, \\ 1111 Budapest, Müegyetem rkp. 3. K 282. Tel.: (+36-1) 463-1330 \\ E-mail: mezos@eptort.bme.hu
}

Két évtized különbséggel született Baja városában három fiatalember, akik az érettségi vizsga letétele után a Magyar Királyi József Nádor Műegyetemen az Építészeti Osztály, majd Kar hallgatói lettek. Mindhármójuk elnyerte a legrangosabb hazai állami kitüntetést, a Kossuth-díjat. Major Máté és Hajnóczi Gyula a Kar professzorai és a Magyar Tudományos Akadémia tagjai lettek. A legidősebb, Miskolczy László pedig gyakorló tervezőként vált a hazai építészet kiemelkedő alkotójává. Míg Major és Hajnóczi pályája a Mủegyetemhez, közelebbről az építészettörténet oktatásához kötődött, addig Miskolczy 1956ban, néhány hónappal a rangos elismerés átvétele után az Egyesült Államokba emigrált. Szerkezettervezőként új, választott hazájában ért el sikereket.

A dolgozat az azonos környezetből, egy kisvárosi értelmiségi, középosztálybeli családból induló, azonos hivatást választó és Magyarországon a legrangosabb kitüntetést elnyerő építészekre emlékezik. Miskolczy születésének 2020-ban lesz 120., Hajnóczi születésének pedig 100. évfordulója. Az évfordulókat kutatva derült ki, hogy Majort akadémiai levelező taggá 70 évvel ezelőtt, 1949-ben választották.

A fellelhető adatok alapján részlegesen rekonstruálható volt Miskolczy László hazai munkássága. Az elegáns bajai I. világháborús emlékmütől a Haditengerészeti emlékmüvön át néhány bérház, lakóház és középület megvalósult terveiig. A csúcspontot Miskolczy esetében feltétlenül a mátraházi kórház jelentette, a maga organikus kapcsolatai miatt.

Major Máté professzor pályája tervező építészként a tatabányai élmunkás házak tervezésével 1949ben lezárult. A két háború közötti szakmapolitikai tevékenysége professzori kinevezésének elnyerése után teljesedett ki. Építészetelméleti munkássága mind a hazai, mind pedig a nemzetközi szakirodalomban visszhangra talált.

Hajnóczi Gyula az antik építészet európai jelentőségű kutatójaként és helyreállítójaként vált ismertté. Az aquincumi romkert bemutatásának és kivitelezésének tervezőjeként részesévé vált szinte valamennyi római kori emlék revitalizációjának. Építészetelméleti munkássága egy sajátos építészeti térelmélet bevezetőjének megalkotásában befejezetlen maradt, de gondolatai segítették az utódok gondolkodásának kialakulását a térfogalom megismerése területén.

Kulcsszavak: Miskolczy László, Major Máté, Hajnóczi Gyula, bajai születésủ Kossuth-díjas építészek

Miskolczy László (1900-1974), Major Máté (1904-1986) és Hajnóczi Gyula (19201996), mindhárman Baja szülöttei és nyolc éven át a bajai ciszterci III. Béla Főgimnázium növendékei voltak. Miskolczy 1918-ban, Major 1922-ben és Hajnóczi 1938-ban érettségizett. Mindegyikük a Müegyetemen szerzett építész diplomát (1922, 1927, 1950), és közülük ketten akadémikusok lettek. Majort 1949-ben leve- 
lező, 1960-ban rendes taggá, Hajnóczit 1996-ban levelező taggá választották. Oktatóként-kutatóként - Major is és Hajnóczi is - életüket a Müegyetem Építészettörténet Tanszékéhez kötötték.

A két háború közötti időszakból nagyon kevés bajai fiatalemberről tudjuk, hogy tanulmányaikat a budapesti Müegyetem Építészmérnöki Karán folytatták volna. Különérdekesség ezért, hogy mindhármanjelentős karriert futottak be. Munkásságukat Hajnóczi kivételével, a legmagasabb hazai kitüntetés 1948-as megalapítása után viszonylag korán Kossuth-díjjal jutalmazták. Major 1949-ben, Miskolczy 1955-ben nyerte el a díjat. Hajnóczi Gyula a rendszerváltás utáni első nagy kitüntetési hullámban, 1990-ben - többek között a posztumusz kitüntetett Dohnányi Ernő, Hamvas Béla, Huszárik Zoltán, Márai Sándor, vagy az egykori tanítvány Latinovits Zoltán mellett - Csoóri Sándorral és Gyarmathy Tihamérral vagy a pályatárs Makovecz Imrével vehette át az elismerést. A szülőváros is értékelte az itthon maradottak életművét. Major Máté 1974-ben, Hajnóczi Gyula már halála után, 1996 őszén lett Baja város díszpolgára.

A három kitüntetett építész közül Miskolczy László életmüvéről szinte alig tudunk valamit. Bonta János professzor szóbeli közlése szerint a forradalom elött az Építésszövetség titkáraként is tevékenykedett tervezői munkássága mellett. Egykori munkahelyeinek irattáraiban nem sikerült nyomára akadnunk életútja fontosabb alkotásai felsorolásának. Lányai az Egyesült Államokban élnek, a birtokukban lévő, egy mappában összegyüjtött hagyatékát az Építészeti Múzeumnak adományozták. A forrásanyag feldolgozása és publikálása a mai napig nem történt meg. A gyüjtemény mai állapotában pedig sajnos nem kutatható. Szülővárosa történetében a Miskolczy család jelentős szerepet töltött be. Két bátyja közül Dezső orvos, az elmekórtan kutatója a Magyar Tudományos Akadémia rendes tagja lett és a háború előtt jelentős tudományos kapcsolatrendszert épített ki. Miskolczy Dezső felesége, a mai napig nagyra becsült egykori bajai polgármester, Borbíró Ferenc kisebbik lánya, Márta volt, aki később Szent-Györgyi Albert második felesége lett. László fiatalabb bátyja, Ferenc Baján tisztelt festőművészként és grafikusként alkotott. Lakóházát, melyet Baján csak Bagolyvárként ismernek, öccse tervezte. Így források hiányában csak nagyon kevés ismerettel rendelkezünk Miskolczy László életútjáról.

Miskolczy László (1. ábra) tervező építészként, szerkezettervezőként, illetve statikusként dolgozott. A háború után az IPARTERV, majd a LAKÓTERV munkatársa lett. Az IPARTERVben végzett munkájáért 1951-ben a Magyar Népköztársasági Érdemrend ezüst fokozatát ${ }^{1}$ kapta meg. Alig négy esztendő elmúltával, már a LAKÓTERV építészeként végzett szerkezetfejlesztő munkásságáért 1955-ben elnyerte a Kossuth-díj III. fokozatát. Laudációja szerint: „A lakóházak és lakótelepek korszerü, gyors és gazdaságos megépítése érdekében kidolgozott, a tömeges előre-

${ }^{1}$ Közli az Épités Épitészet - Az Épitómüvészet, Tudomány és Gyakorlat lapja 3 (1951) 4. 260. A szakma kitüntetettjei. 


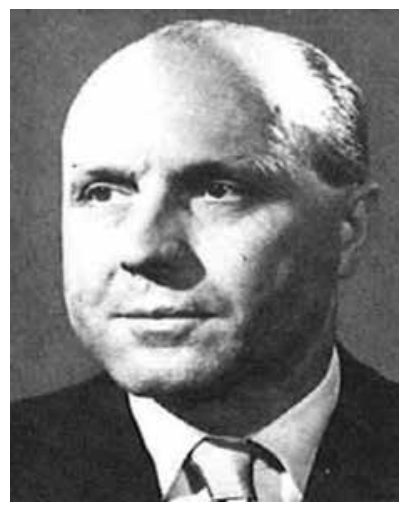

1. ábra. Miskolczy László*

gyártásra alkalmas szerkezeti elemek müszaki terveiért, köztük a legjelentősebbet, az import faanyagot teljes mértékben helyettesítő, előre gyártott vasbeton fedélszék tervéért"2 kapta a kitüntetést. 1956-ban az USA-ba emigrált és New Yorkban a világhírü Skidmore, Owings \& Merill iroda munkatársa lett haláláig.

Miskolczy építészettörténeti érdeklődését bizonyítja, hogy többek között Padányi Gulyás Jenővel 1940-ben megalakította a Magyar Ház Köre elnevezésű társaságot és az Építészettörténet Tanszék néhai docensével, Vargha Lászlóval, 1943-ban közösen publikálta A Nagykunság vidék népének építészete ${ }^{3}$ címü kis kötetet.

Miskolczy László pályája gyakorlatilag föltáratlan. Diplomájának megszerzése után nyilván egy neves pályatárs irodájában helyezkedett el, hogy az egyetemen elsajátított elméleti tudás mellé megszerezze a szakma gyakorlásához elengedhetetlen praktikus ismereteket is. Padányi Gulyás Jenővel bizonyára nem csak a népi építészeti kutatások kapcsán került kapcsolatba. 1933-ban készült el a bajai Déri-kertben ${ }^{4}$ a város I. világháborús emlékmúve (2. ábra). A 23 m magas, fehér mészkőlapokkal burkolt hasáb tervezőjeként Padányit nevezi meg a szakirodalom. Miskolczy László tervezőként, testvéröccse, Ferenc grafikusként szerepel a terven. Néhány adat arra utal, hogy 1937-ben közösen tervezték meg a Petőfi híd budai hídföjénél megépített „Haditengerész” emlékmüvet ${ }^{5}$ (3. ábra). A szintén fehér mészkőlapokkal burkolt talpazat a Navarra hadihajó orrát mintázta. A talpazaton a fiumei világítótorony ki-

* A tanulmány képei a Szerző archívumából származnak.

${ }^{2}$ Kossuth-díjasok és Állami Díjasok Almanachja. Akadémiai Kiadó, Budapest 1988. 242.

${ }^{3}$ Miskolczy László - Vargha László: A Nagykunság vidék népének épitészete. Magyar Ház Barátainak Kiadása, Budapest 1943.

${ }^{4}$ A Rerrich Béla által tervezett park méltó környezete volt a hófehér mészkőlapokkal burkolt, hasáb alakú obeliszknek. Sajnos a kert elveszítette eredeti progresszív kertépítészeti karakterét az utóbbi, kevéssé szakszerünek mondható ,felújításoknak” köszönhetően.

${ }^{5}$ 1937. október 10-én avatták föl a 22 m magas, világítótornyot formáló emlékmủvet. A monumentális bronz alakokat Szentgyörgyi István szobrászművész készítette. 


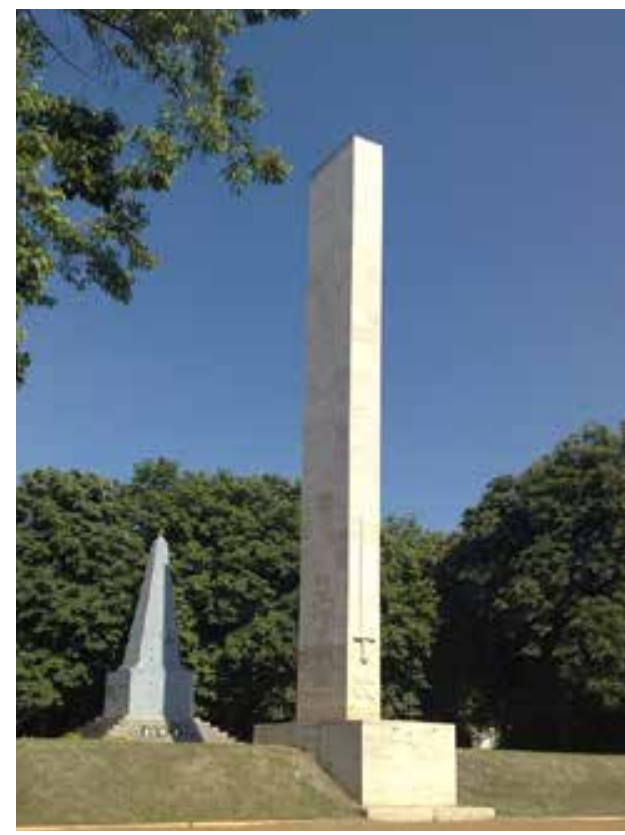

2. ábra. Baja, Déri-kert, I. világháborús emlékmủ

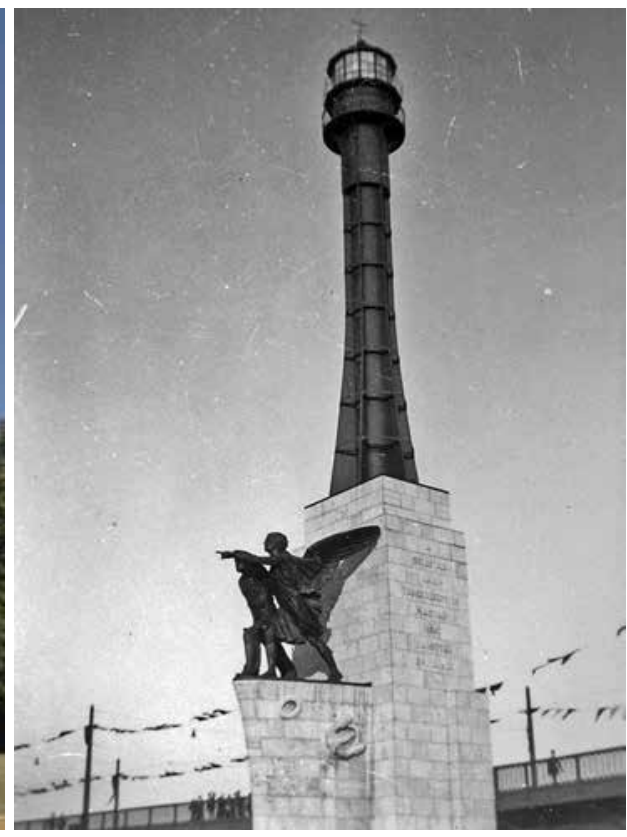

3. ábra. Haditengerész emlékmủ a Petőfi (egykori Horthy Miklós) híd budai hídföjében

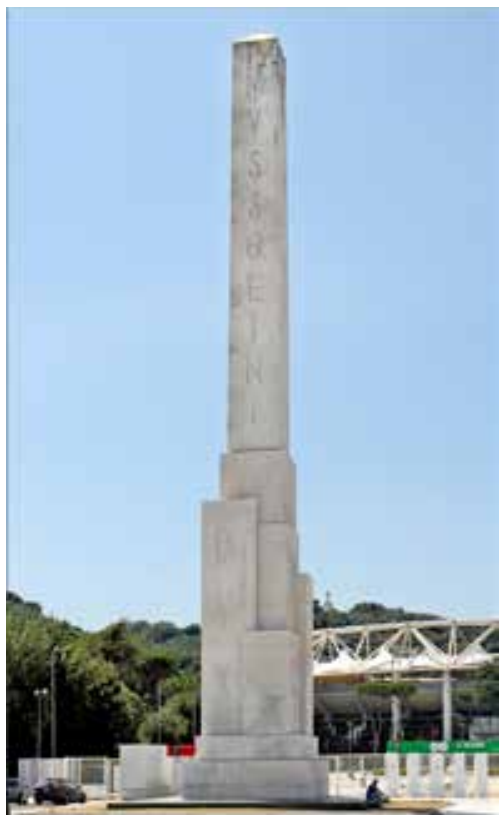

4. ábra. Mussolini Dux obelisc a római Foro Italicón 
csinyített mását fémből készítették el. Különösen a bajai emlékmű erőteljes itáliai hatást mutat. Mussolini hatalomra kerülése után számos modern obeliszket állítottak föl Itáliában. Ezeket egyetlenegy kivételével lerombolták. A kivétel a Foro Italicón (eredetileg Foro Mussolini) fölállított, egyetlen tömbből kifaragott, carrarai márvány emlékmű volt Mussolini Dux felirattal (4. ábra). A 17,4 m magas tömb tervezője Enrico del Dubbio volt, a felállítás éve 1932.

Miskolczy László néhány épülete is ismert Budapesten. A Csonka családhoz füződő korai kapcsolatát igazolja, hogy az építési vállalkozó Csonka László részére 1928-1929-ben épített egy villát a Gellért-hegyen, a Kelenhegyi út 37. szám alatt. Bolla Zoltán véleménye szerint a lakóház art deco jegyeket visel magán. ${ }^{6}$ A Korbuly testvérek számára egy bérháza épült 1937-ben a Szerb utca 17-19.-ben (5. ábra).

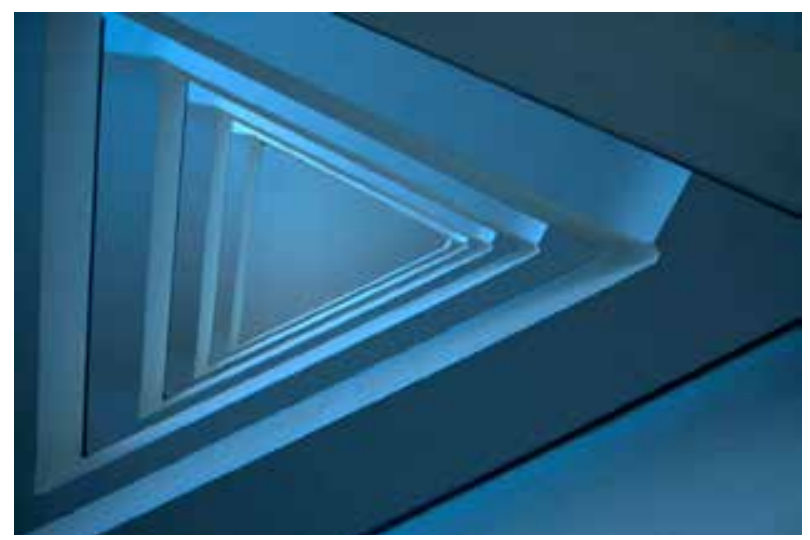

5. ábra. Budapest, Szerb u. 17-19. bérház lépcsőháza

A Fővárosi Levéltár adatbázisában lelhető föl az 1938-1940 között épült, Minerva utca 15. szám alatti, Szöges János építészmérnök számára tervezett családi ház. ${ }^{7} \mathrm{Nem}$ ismert, hogy Szöges mennyire volt gyakorló építész, talán inkább építési vállalkozó lehetett. Miskolczy szakmai elismertségét erősíti viszont, hogy egy kolléga kérte föl saját háza megtervezésére. Eredeti gondolatokat hordoz a megépült csepeli községháza terve. Mára sajnos jellegtelen és érdektelen épületté silányult az átépítések következtében (6.a-b ábra).

A háború végéig terjedő évek alkotásai közül a mátraházi kórház terveinek elkészítése jelentős mérföldkő Miskolczy ismert életmüvében. A Csonka család építőipari vállalkozó tagja, a porlasztó felfedezőjének, Csonka Jánosnak a testvéröccse,

${ }^{6}$ Bolla Zoltán: Magyar art deco építészet. Ariton Kft., Budapest 2018. 173.

${ }^{7}$ A Minerva utca 15. szám alatti épület tervanyagát Budapest Főváros Levéltára őrzi. A statikai terveket Hegedüs Béla készítette. HU BFL - XV.17.d.329 - 5435/3, 1-5., 9-16. f. Az épület mai formájában kissé átépített, az elhanyagolt kert miatt az utcáról csaknem fényképezhetetlen. 

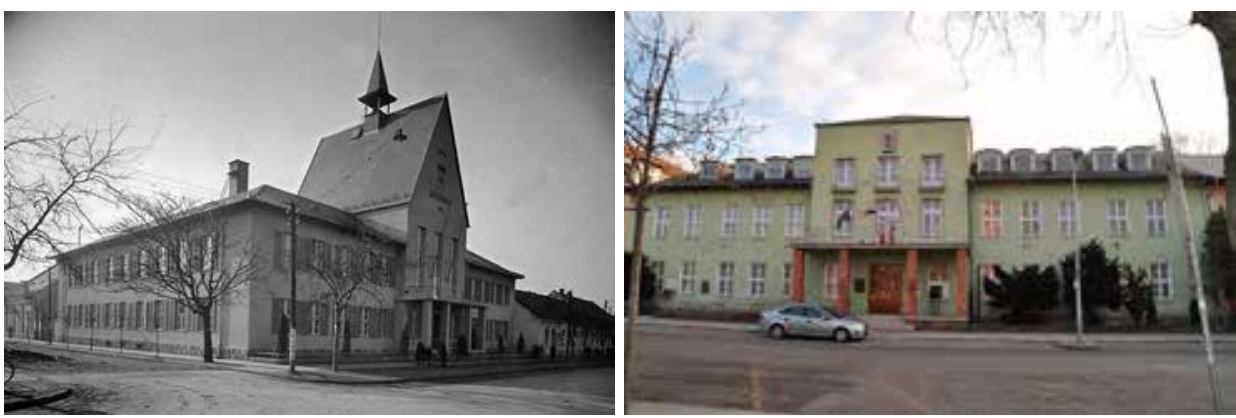

6.a-b ábra. Budapest, XXI. kerületi Városháza egykor és ma

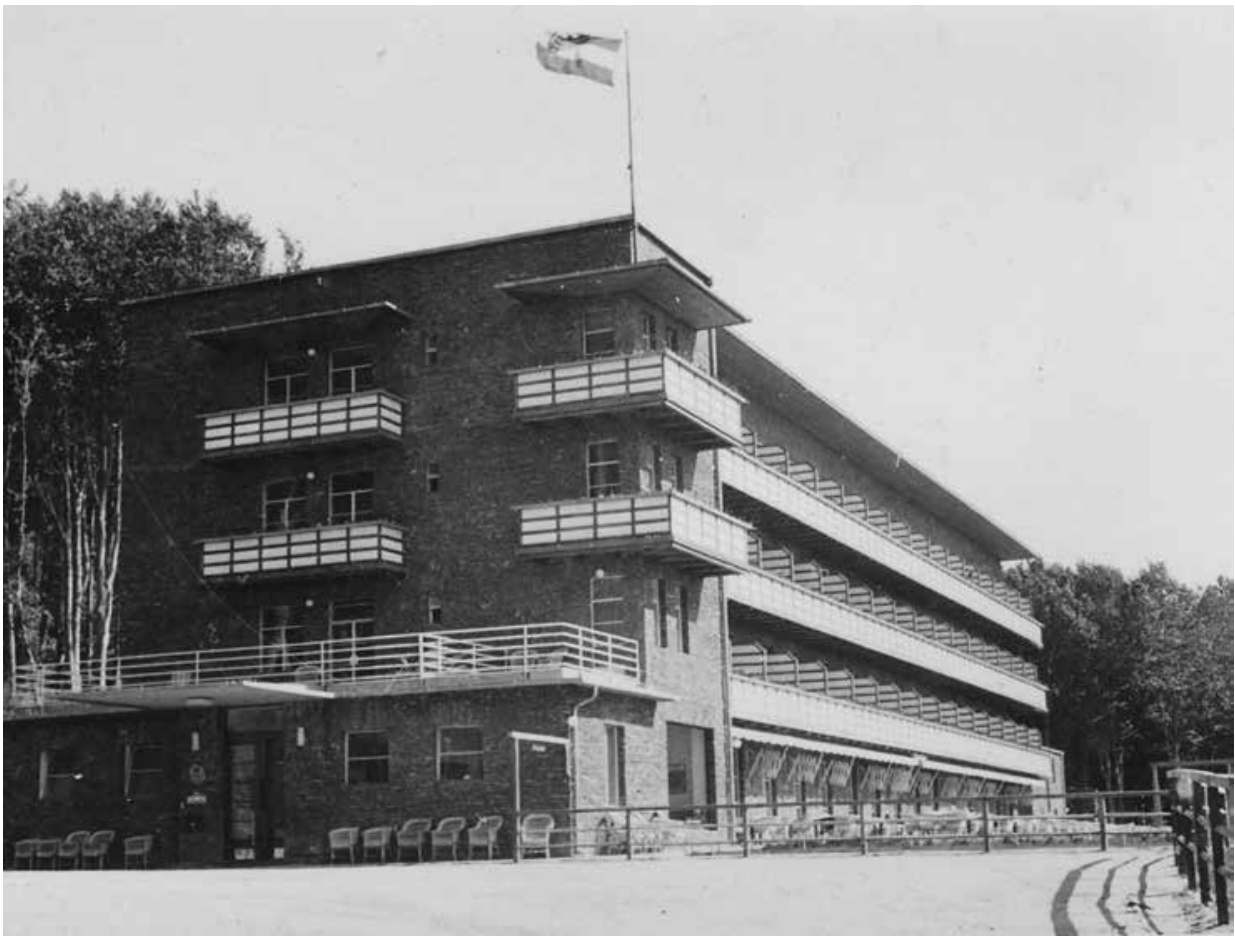

7. ábra. Mátraháza, szanatórium, A épület

László finanszírozásában épült föl a komplexum. Miskolczy László mellett Csonka Ferenc jegyzi a terveket. A csaknem svájci minőségü gyógyklíma, az igényes kialakítás és a színvonalas orvosi ellátás jellemezte, 1934-ben épült, ma „A” szárnyként (7. ábra) jelzett épület után a tervezőpáros elkészítette a háború nehézségei ellenére 


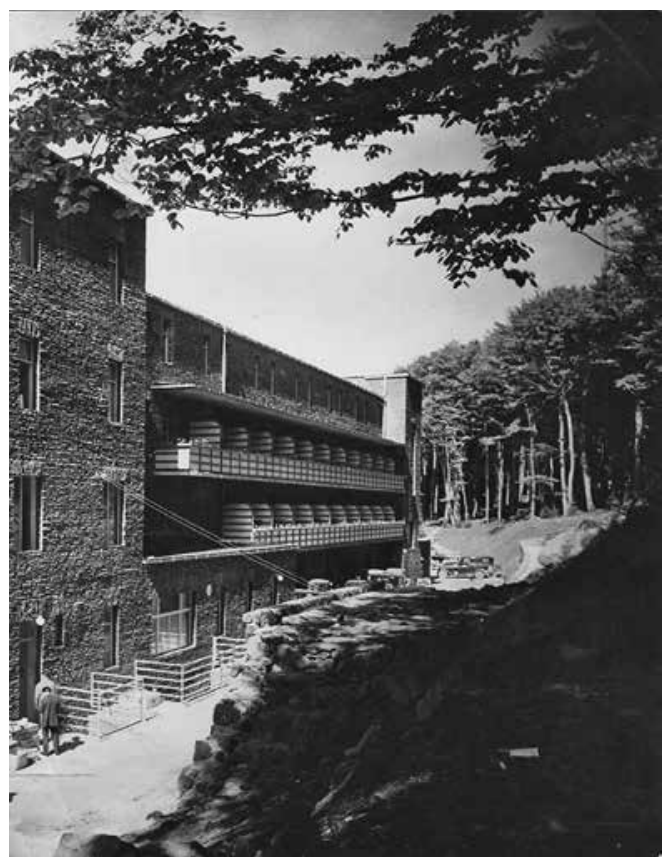

8. ábra. Mátraháza, szanatórium, B épület

is a második, mai jelöléssel „B” épületet (8. ábra) és 1943-ban a két elem kapcsolatát biztosító íves összekötő szárnyat (9. ábra).

A földszint +3 emeletes, terméskő burkolatú középfolyosós épület a kor igényeit messzemenően kielégítette, de a szintenként közös fürdőszoba és a mai igényekhez képest viszonylag szük szobák a 21. század elvárásait már nem tudják kielégíteni. Ez is és persze az egészségügyben meglévő forráshiány is magyarázza az egykori luxus fényének az elhalványulását. Pedig a homlokzatok kőburkolata és az „A” épületen fából ácsolt loggiasor korai kapcsolatot sejtet az organikus építészet korabeli amerikai alkotásaival. Úgyszintén az „A” épületszárnyhoz második ütemként megépített étterem félköríves alaprajzi formája, nagy ablakfelülete is figyelemreméltó gesztusnak számít. Abban az időben, az 1930-as évek elején ezt a megoldást csak kevesen és csak azok alkalmazták, akik kapcsolatba kerültek a Bauhaus meghatározó építészeti gondolkodásával. Nem tudjuk, hogy Miskolczynak Csonka Ferenccel közösen jegyzett munkája mennyiben tükrözi Miskolczy Lászlónak az építészetről vallott felfogását, vagy mennyiben tekinthető Csonka kreatív alkotótársnak.

Miskolczy első mátraházi munkáját, a korszak ünnepelt írónője, Tormay Cécile számára tervezett nyaralóját anyaghasználatában a kékesi szanatóriumegyüttes elöképének tekinthetjük. A kő alkalmazása a homlokzaton és a nagy ablakfelület feltét- 


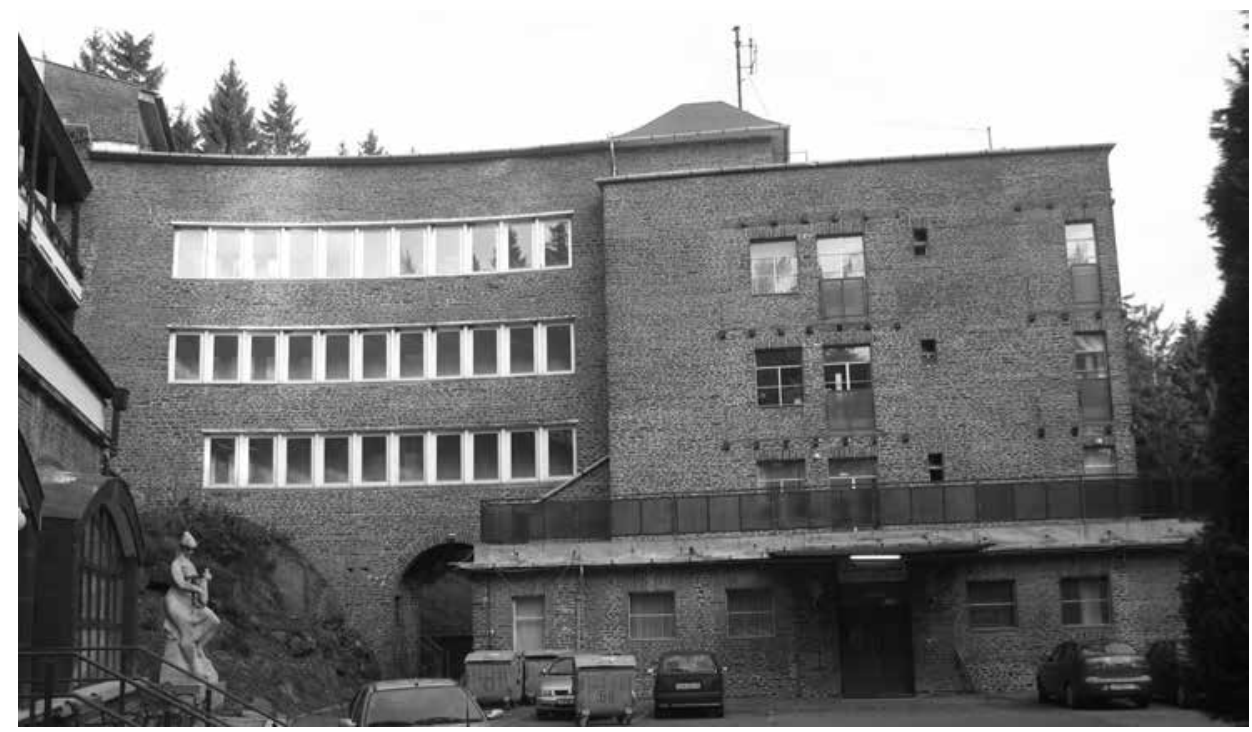

9. ábra. Mátraháza, szanatórium, összekötő szárny

lenül a korszerünek vélt gondolat megjelenését tükrözi. Az erőteljesen tagolt tömeg, a föhomlokzaton megjelenő markáns szegmensíves nyíláskeretezés talán inkább a hagyományok megtartásának szándékára utal. Az írónő „Meseháznak” nevezte az épületet. 1937-ben bekövetkezett haláláig gyakorlatilag Mátraházán élt ${ }^{8}$ (10. ábra).

Karakteres alkotás a velencei vasútállomás kis fogadóépülete. Tömegalakításában és homlokzati megformálásában egyértelmúen rokonítható az 1943-ban összeállított, a Nagykunság építészetét bemutató füzetben publikált példák formavilágával, a népi építészetet ihlető forrásként alkalmazó szándékokkal. A csepeli városháza terve mai formájában jellegtelen, semmilyen eredeti gondolatot nem hordozó alkotás. Viszont történeti fotókon látszik a szándék, ami feltétlenül a modern építészet korai időszakához kapcsolja az épületet. Talán leginkább Heinrich Tessenow építészetéhez áll közel az épület. Tessenow az I. világháború utáni generáció - Peter Behrens, Bruno Taut, Hans Poelzig - nemzedékéhez tartozott, akikre mesterként tekintett a náluk egy évtizeddel fiatalabb, egyetemes értelemben is nagy generációnak tartott német triász: Mendelsohn, Gropius és Mies van der Rohe.

Az építészettörténetben szinte ismeretlen alkotása Miskolczynak a bajai festő öcs, Miskolczy Ferenc számára tervezett kis klinkertégla burkolatú müteremháza, a „Bagolyvár”. Az épület a Sugovica egykori török hadi kikötőjére néző magaslaton

${ }^{8}$ Érdemes megjegyezni, hogy az eredetileg Tormay Bélánénak 1913 körül tervezett, idővel lánya, Tormay Cécile tulajdonába került Budapest, Szalonka út 6/a szám alatti villa egészen más karakterü épület volt. Tervezője a fiatalon elhunyt Zrumeczky Dezső volt.

${ }^{9} \mathrm{Az}$ épület fotózhatatlan, az eredeti tervek esetleg Miskolczy Ferenc hagyatékában fellelhetőek. 


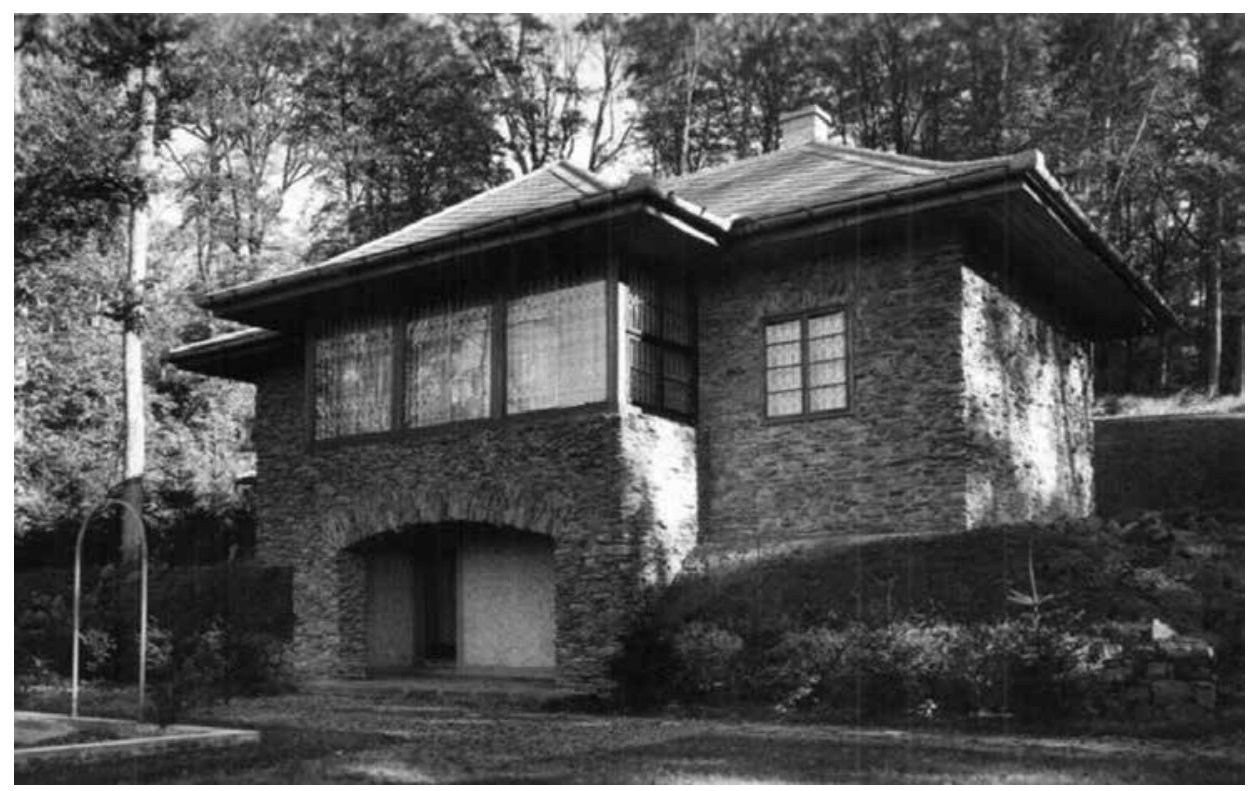

10. ábra. Tormay Cécile nyaralója Mátraházán, a „Meseház”

áll a Parti utcában. A homlokzati burkolatkezelés talán leginkább Frank Lloyd Wright 1889-ben épített Oak parki (Illinois) saját müteremházának anyaghasználatára emlékeztet. Tömegformálásában és alaprajzában pedig igazodik a magas part geomorfológiai adottságaihoz.

A Miskolczy László épületein megjelenített építészeti minőség a szerző egyértelmü építészi kvalitását igazolja. Vonzódását és bizonyos mértékben ismereteit a századforduló organikus építészetéről a bemutatott néhány alkotása is bizonyítja. A háborút követő évtizedben a forradalomig az IPARTERVben, majd a LAKÓTERVben eltöltött éveinek munkássága alapján Miskolczyt inkább szerkezettervezőként tarthatjuk számon.

Két tervvázlatát ismerjük a háborút követő korszakból. Mindkettőt a mai Nyugati térre tervezte. Az egyik, a Váci út és a tér által határolt, azóta elbontott hatalmas irodaépület bővítése lett volna. A másik épületet az egykori Skála Metró áruház helyére tervezte. Mindkét látványtervnél szerzőtársként feltüntette a festő öcs, Miskolczy Ferenc nevét is. Az igényes akvarelleken ábrázolt látványtervek későbbi sorsáról nincs információnk. Annyi bizton állítható, hogy a tervek nem valósultak meg.

Kollégák szóbeli közlése alapján állítható, hogy amerikai évei során is inkább konstruktőri képességét kamatoztatta. Kitüntetéseit is ilyen típusú feladatok színvonalas megoldásáért kapta. 


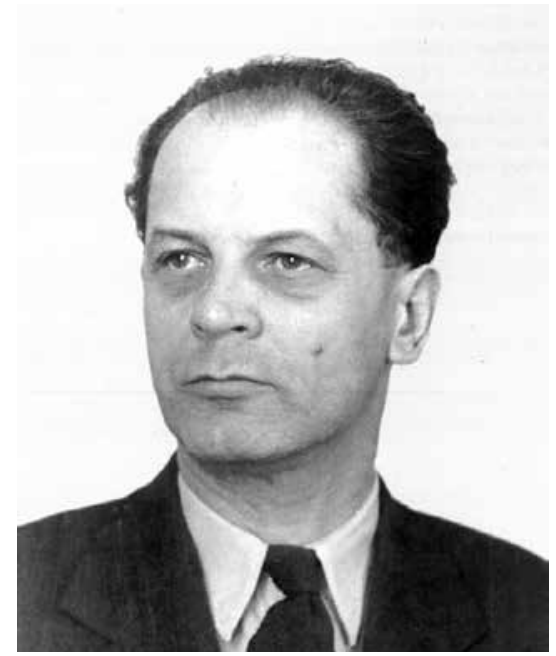

11. ábra. Major Máté

Major Máté (11. ábra) diplomájának megszerzését követően előbb magántervezöként dolgozott, majd 1936-tól az OTI munkatársa lett. Pályafutásának korai időszakában a modern építészet elkötelezett híveként és propagátoraként maga is néhány épület tervezője vagy társtervezője volt. Talán legismertebb alkotása az I. kerületi Attila út 127. szám alatti lakóház Budapesten (12. ábra) - amelyet Detre Pállal közösen tervezett - 1933-1934-ben épült meg. Amint Major az önéletírásában leírja: „A tervezés lényegi részét én végeztem, a koncepciót emeletenként egy lépcsőházhoz kapcsolt négy lakással, és a homlokzatokat én csináltam meg, az egyéb részletterveket maga a vállalkozó Koch Károly és fia cég." 10 Az utcai fronton viszonylag keskeny telken az utcára merőlegesen állított hatszintes épület középre helyezett lépcsőházából szintenként így 2-2 lakás volt megközelíthető (13. ábra). A beépítés adottságából következően a hosszan elnyúló épületben a lakások is alapvetően hosszanti kompozíciót mutatnak. A logikusan elhelyezett, bejárathoz kapcsolódó konyha- és fürdőszobacsoporttal egy vonalban a kétszobás lakás hálószobája, mellette a hosszú és emiatt részben rosszul bevilágított nappali helyezkedik el. A homlokzat az Attila útra néz a Bauhaus kompozíciós elveinek megfelelően kissé visszahúzott földszinttel, fölötte öt emelet széles, szalagszerüen elképzelt ablakokkal. Színkezelésében a kor modernista épületeire jellemzően fehér színű falfelületeket alkalmazott. Az ablakok színhasználata már nem követte az elöképeket, egyszerü, fehér színủ nyíláskeretezés mellett a megszokott mustársárga redőnyszín adta az épület megjelenéséhez szükséges színvilágot. Az épületről ismertetést közölt a korszak meghatározó folyóirata a Tér és Forma 1935-ben. Még ebben az évben egy belga lap is ismertetést közölt az Attila utcai házról - ezzel kapcsolatban Major

\footnotetext{
${ }^{10}$ Major Máté: Férfikor Budapesten. Szépirodalmi Könyvkiadó, Budapest 1978. 237.
} 

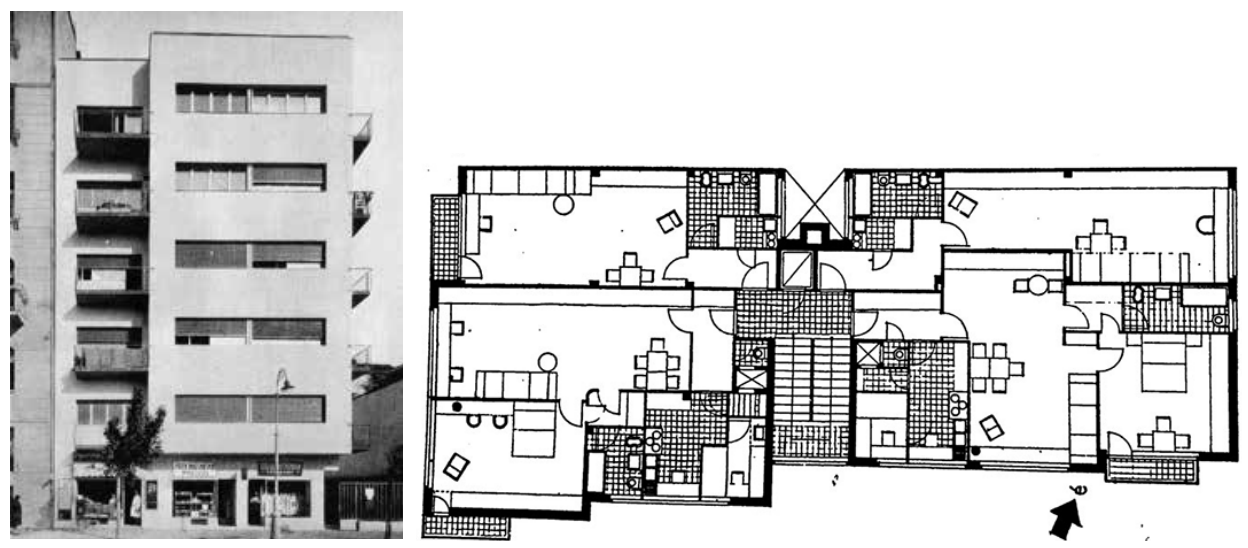

12. ábra. Budapest, Attila út 127. bérház (Tér és Forma 1935. 1. 15.).

13. ábra. Budapest, Attila út 127. bérház, emeleti alaprajz (Tér és Forma 1935. 1. 15.)

keserüen jegyzi meg, hogy „,egyedül csak Detre Pál neve szerepel szerzőként a képek alatt". ${ }^{11}$

Tatabánya Óváros területén a bányászváros fejlesztésének keretében új lakóházakat emeltek. Ismereteink szerint Major Máté háború után megépült épületei, az úgynevezett „élmunkás” házak 1949-ben készültek el. A szintenként négylakásos, négyszintes négy lakóház az egykori Ságvári Endre, mai nevén Szent Borbála úton áll.

Major már a háborút megelőző időszakban is aktív szakmai-politikai tevékenységet folytatott. Tagja volt a CIAM magyar csoportjának és a Tér és Forma szerkesztőbizottságának. Az MKP tagjaként 1933-1937 között a Szocialista Képzőmüvészek Csoportja titkáraként is tevékenykedett. A háború után 1946-tól szerkesztette az Új Épitészetet, majd annak megszüntetését követően az Épités - Épitészet c. folyóiratot is. A párt delegáltjaként adminisztratív beosztásba került. Előbb építésügyi kormánybiztosként, majd az Építés- és Közmunkaügyi Minisztérium föosztályvezetőjeként dolgozott. 1948 öszi félévétől került a Müegyetemre, bár tudományos vagy oktatói ambíciói - saját bevallása szerint - nem voltak. „Küldetésem oka egyébként az volt - vallja Major ${ }^{12}$-, hogy a Királyi József Nádor Müegyetem oktató személyzete tulajdonképpen érintetlenül vészelte át a világháborút 1945-től 1948-ig. Az egyetemnek akkor még meg volt az autonómiája, s miként tette ezt, főleg a nyilas uralom idején, ugyanúgy védte a felszabadulás után is", és státuszát megörizve vitte tovább az oktatás-nevelés ügyét. Nyilvános rendes tanári kinevezése 1948. december 8-i keltezésü. Első egyetemi munkahelye az akkor vezető nélküli Magasépítési Tanszék volt, amelyet Pecz Samu alapított, és utolsó vezetője Kotsis Endre volt. Az

\footnotetext{
${ }^{11}$ Uo.

${ }^{12}$ Major Máté: Tizenkét nehéz esztendő (1945-1956). Lapis Angularis III. Források a Magyar Építészeti Múzeum gyüjteményéből. MÉM, Budapest 2001. 211.
} 
Általános Építészeti Tanszékre átnevezett egységben a Major által oktatott tárgy, a Bevezetés az épitészetbe heti 4 előadási és 2 gyakorlati órájával akkor az első és egyetlen ideológiai megalapozottságú tárgy volt a Karon. A köztársasági elnök még 1948. december 14-i napjával, az újonnan létrehozott Magyar Tudományos Tanács tagjává nevezte ki Majort. A Tanácsnak a Tudományos Akadémiába történt beolvasztása következményeként Major Mátét 1949. október 31-én az MTA VI. osztálya ${ }^{13}$ levelező taggá választotta. A Tudományos Minősítő Bizottság 1951-ben visszamenőleges hatállyal a műszaki tudomány doktorává avatta.

Az ő számára is váratlan volt a hír 1949 nyarán, hogy az 1949-1950-es tanévtől kezdve az alma mater Ókori Építészettörténet Tanszékének vezetőjévé nevezik ki, és az építészettörténet tárgy több ciklusának előadásaira kell felkészülnie. A Pártközpont Oktatási Bizottságának illetékese szerint az „....amit marxistaként hozzáad az [építészettörténethez MT] is több, mint ami eddig volt". ${ }^{14}$ Hatalmas energiával vetette bele magát a munkába. A korábbi, döntően stílustörténetet oktató müegyetemi képzés helyett az építészettörténetet saját korába ágyazva, „... annak gazdasági-társadalmi alapjáról, politikatörténetéről, felépítményének alakulásáról, vagyis tudománya és müvészete egyes ágainak mozgásáról, változásáról, fejlődéséről annak hangsúlyozásával beszélt, hogy az építészet mindezzel szoros kapcsolatban, kölcsönhatásban van, de csakis saját törvényszerüségei érvényesülnek benne". ${ }^{15}$ A sors fintora, hogy Major Blaise Pascal és az elkötelezett marxista, Aldous Huxley nyomán ismeri fel, hogy az „...építészet szorosan összefügg a korral, a társadalommal és a történelemmel..."16. Háromkötetes tankönyvében érvényesíti felismerését. Az 1954-ben megjelent Ösközösségi és rabszolgatartó társadalmak, majd az 1955-ös Feudális társadalmak épitészete címủ kötetek építészettörténeti mondanivalója talán nem tükrözte korának, a 20. század közepének az építészettörténetről vallott nézeteit. Újdonságértékét a kötetek az építészet kialakulásának környezetét és a tárgyalt időszak kultúráját, mindenekelőtt irodalmát és képzőművészetét bemutató passzusai adják. Munkájának harmadik kötete, a tőkés társadalmak építészete a felvilágosodás korától dolgozza fel a 18-19. század építészettörténetét - 1959-ben jelent meg. Elárulja Major szemléletét, hogy a szívéhez közel álló modern építészet fél évszázadát az előző fejezettel megegyező terjedelemben tárgyalja. Kötetének záró fejezete, a szocializmust építő társadalmak alkotásait bemutató fejezet a kötetnek alig 10\%-át teszi ki, és szinte kizárólag a Szovjetunió építészetének bemutatását tartalmazza.

1959-ben irányítása alatt egyesült a Rados Jenő professzor által vezetett Középkori és a Kardos György halálát követően Pogány Frigyes professzor által irányított Újkori Építészettörténet Tanszék, melyekből alapító igazgatóként Major Máté szervezte meg 1972-ben az Építészettörténeti és Elméleti Intézetet.

Egyetemi professzorként is folytatta aktív szakmapolitikai és szervező munkáját. Legjelentősebb szerepvállalása az MDP Agitációs és Propaganda Osztálya szervezé-

\footnotetext{
${ }^{13}$ I. m. 215. Az MTA VI. Müszaki Tudományok Osztálya.

${ }^{14}$ I. m. 233.

${ }^{15}$ Uo.

${ }^{16}$ I. m. 178.
} 
sében lezajlott nagy építészvitában fölvállalt véleménynyilvánítása ${ }^{17}$ volt. A vitában a Rákosi korszak kultúrájának irányítója, Révai József képviselte a „,vádat”. Az állami ideológia nevében Perényi Imre, a BME későbbi rektora, Lukács György filozófus és sokan mások igyekeztek igazolni a magyar építészet elkötelezett szocialista elhivatottságának a szükségességét. Ezzel szemben Major, aki már hallgatóként és diplomájának megszerzését követően is a modern építészet elkötelezett hívéül szegődött és részese volt az 1930-as évek baloldali képzőmüvész és építész törekvései valóra váltásának, az építészetnek a Szovjetunióban megfigyelhető útkeresését is tévedésként értékelte. Perényi és Major korábban közzétett vitairata alapján - a viszszaemlékezők egyöntetü véleménye szerint - nehezen indult el a vita ${ }^{18}$ a Magyar Dolgozók Pártja Akadémia utcai székházában. Az első érdemi felszólaló Lukács György filozófus volt. Lukács az Esztétikum sajátossága c. nagy munkájában feltünően igazolta érzéketlenségét (talán a meg nem értését is) az építészet iránt. ${ }^{19}$ Felszólalása is bizonyítja, hogy tökéletesen félreértette Major gondolatait. A vitában az ,alperes” szerepét betöltő szerző inkriminált mondata szerint: ,...csak a »fizikailag« igazán használható épület lehet »esztétikailag« is tökéletes, és csak az »esztétikailag« teljes építészet lehet »fizikailag« is jól használható.” Lukács értelmezésében Major kijelentése azt jelenti - amint Ernst Jünger expresszionista német író és filozófus a Sturm und Drang korszak képviselőjeként interpretálta: egy vasúti menetrend van olyan érdekes, mint Tolsztoj legszebb regénye. Ez durva összekapcsolása mondja Lukács - a mindennapi használhatóságnak és az abból automatikusan kinövő szépségnek. ${ }^{20}$ Major szellemes riposztja: „A szépség és a praktikum ilyen összekapcsolása egyébként még a Neue Sachlichkeit burzsoá megfogalmazásánál is régibb, sokkal régibb, már Xenophón ad »Visszaemlékezések« címü müvében Szókratész szájába ilyenféle megállapításokat..."21 Major a vitában alulmaradt. Nyilván a hozzászólók között sokan voltak, akik őszintén vagy érdekből azonosultak a párt álláspontjával. A kevesek közül is csak néhány résztvevő merte fölvállalni ellenvéleményét. Amint Bernáth Aurél a korszak ünnepelt festője fogalmazott: „Amikor ... tölem megkérdezték és ... hitet tettem, hogy Munkácsyhozigazodjunk-e vagy Nagybányához ..., azt mondottam, hogy Nagybányához igazodjunk. Miért? Mert abban van még hatóerő ... abban van még élő számunkra. Munkácsy számunkra nem élő ... Tehát oda ... kapcsolódjunk ... ahonnan valami elánt tudunk kapni." ${ }^{22}$

\footnotetext{
${ }^{17} \mathrm{Az}$ utókor gyakran őszintétlennek ítéli Major szerepét a vitában. Számomra az életút egyértelműen igazolja, hogy mindaz, amit képviselt 1951-ben, meghatározta egész későbbi pályafutását még akkor is, ha politikai értelemben emiatt sérült a szakmai karrier.

${ }^{18}$ A „Vita építészetünk helyzetéről” című monstre rendezvényt 1951. április 17-én és 24-én rendezték meg. Célja az építészet irányvonalának egyértelmű rögzítése volt a nyugati dekadens, modernista építészettel szemben a Szovjetunióban képviselt egyértelmü, ideológiailag elkötelezett szellemiséget tükröző szocialista építészet megteremtése érdekében.

${ }^{19}$ Vö. Lukács György: Az esztétikum sajátossága. II. kötet. Akadémiai Kiadó, Budapest 1975. 373-425.

${ }^{20}$ Major idézi a vitát: Lapis Angularis III. 236.

${ }^{21}$ I. m. 237.

${ }^{22}$ Közli: Major M.: Lapis Angularis III. 238.
} 
A historizáló építészet megvalósítását támogatók győzelme egyben az örök ellenlábas, a neobarokknak tartott Wälder-iskolából kikerült Kardos György sikerét is hozta. Major önszántából vagy külső hatásra lemondott közéleti tisztségeinek legfontosabbjairól, föladta rövid dékánságát az újonnan megszervezett Építészmérnöki Karon és az Építőművész Szövetség elnökségéről való lemondását is felajánlotta. Amint Bonta János Major temetésén a Farkasréti temetőben elmondott beszédében is hangsúlyozta: ${ }^{23}$ a nagy építészvitában elszenvedett vereségét sohasem tudta igazán kiheverni. Évtizeddel később rezignáltan jegyezte meg, hogy az olvadás beköszönte után, ami itthon Nagy Imre miniszterelnökké választását jelentette, senkinek nem jutott eszébe, hogy ismételten dékánnak vagy az egyetem rektorának jelölje. Pedig Hruscsovnak nem csak a XX. kongresszuson elmondott titkos beszéde hozott enyhülést a szocialista táborban. Kevéssé ismert a szovjet építészeti plénumon elhangzott, 1954-es Hruscsov-beszéd, amely alapvető változásokat hozott a szovjet építészetben. A pártvezető ugyanis „....elítélte a szovjet építészeket, amikor a konstruktivista formalizmus végletéből a formalizmus másik végletébe tévedtek: művészkedő túlzásokra ragadtatták magukat...". ${ }^{24}$ A modern építészet szellemének ilyetén való újjászületése után sem nyert Major valódi és teljes rehabilitációt. Tagadhatatlan szakmai tekintélyét kihasználva azonban sokat tett a magyar építészet külföldi megismertetéséért és a korábban dogmatikusnak és kozmopolitának nevezett nyugati építészet hazai elfogadtatásáért, elismeréséért. Az Akadémia tagjaként könyvsorozatok megjelenését szervezte, támogatta. Szellemi irányításával jelent meg 22 kötetben a híres Architektúra sorozat, bemutatva a modern építészet legnagyobb alakjait, akiket Major jórészt személyesen ismerhetett, mint a brazil Oscar Niemeyer, a gyökereiben magyar származású, de Bécsben született és tanult, amerikaivá lett Richard Neutra vagy a barát, a valódi Bauhaus-növendék és későbbi -tanár, a pécsi születésű Breuer Marcell. A neves olasz statikus építész, Pier Luigi Nervi és a külföldön nevet szerzett Breuer, Goldfinger Ernő, valamint Vágó Péter munkásságát maga mutatta be a sorozatban. Tanszékén, későbbi intézetében pedig megteremtette a fiatalok számára az alkotás szabadságát és a színvonalas publikálás lehetőségét. Főszerkesztőként nevével hitelesítette az Akadémia által kiadott, azóta megszünt Acta Technica címü idegen nyelvű folyóiratot. A tudományterület számára előbb az Épités- és Közlekedéstudományi Közlemények ${ }^{25}$ címen, majd a máig létező Épités- Épitészettudomány címmel magyarul megjelenő periodikát jelentette meg föszerkesztőként. Ösztöndíjhoz, utazási lehetőséghez segítette az arra érdemeseket. Tapasztalataikat, élményeiket az Épitészet Világa kis ismeretterjesztő köteteiben foglalhatták össze. Ebben a sorozatban mutatta be Hajnóczi Iraknak nemcsak az ókori Mezopotámiából ismert emlékeit, hanem a

\footnotetext{
${ }^{23}$ Bonta János: Major Máté búcsúztatása. Magyar Épitőmũvészet 77 (1986) 3. 7.

${ }^{24}$ Közli Bonta János: i. m. 280.

${ }^{25}$ A folyóiratot 1957-1968 között jelentette meg az MTA Müszaki Tudományok Osztálya. Szerkezetét tekintve tükrözte a Mủegyetemből kivált Építöipari és Közlekedési Müszaki Egyetem profilját. Major javaslatára az addig két tudományterületet egyesítő folyóiratból az építészet tudományos folyóirata jött létre, a szintén az Akadémia égisze alatt 1969-től évi 4 alkalommal máig megjelenő Épités - Épitészettudomány címü periodika.
} 
kortárs építészet jelentős alkotásait is. Védte munkatársait az ideológiai támadásoktól, ha kellett, és segítette őket pályájukon a fokozatok megszerzésével vagy az egyetemi ranglétrán való emelkedéssel. Ezért volt lehetséges, hogy az építészettörténettel - mint ideológiai diszciplínával - kapcsolatban elvárt marxista szemlélet megjelenése általában nem volt kimutatható a tanszék munkatársainak publikációiban. Így válhatott - az ideológiai teher ellenére ${ }^{26}$ - a 20. század meghatározó építészettörténeti és elméleti műhelyévé a Mủegyetem egykori Építészettörténet Tanszéke.

Nyugdíjasként is rendszeresen bejárt a tanszékre, ahol megtartotta professzori szobáját. Építészeti elveihez élete végéig hủ maradt. Számára az egyetlen helyes építészeti irányzat a modern építészet volt. Írásaival, cikkeivel és könyveivel igyekezett jelen lenni a szükebb szakmai és a tágabb kulturális közéletben. Az 1970-es években elindult változásokkal azonban már nem értett egyet. Az Élet és Irodalom 1975. szeptember 27-i számában megjelent írásában adott hangot véleményének. ${ }^{27}$ A cikk által gerjesztett építészeti vita a hetilap hasábjain Nagy László írásával indult, majd a következő esztendőben a Magyar Épitömüvészetben zárult le. A vitát a fiatal építészek pécsi csoportja által a Hajdúszoboszlói Művelődési Központban szervezett kiállítás és a Csete György építész által tervezett paksi házakon megjelenített, Major értelmezésében tulipán motívumként megjelenő, az építészeti formától idegen díszítés váltotta ki. Major Máté az ún. „tulipános vita” aktív résztvevője volt a sajtóban és más fórumokon egyaránt. Mereven ellenezte a tiszta geometriát megtestesítő panelos építés ,elrontását”, az épületvégeknek tulipánmotívummal való díszítését vagy a Tillai Ernő által alkalmazott megoldást: a paneles épületek loggiasarkainak a TVkészülék képernyőjéhez hasonló lekerekítését. ${ }^{28}$ Különösen irritálta az építészet nyelvében - szerinte szervetlenül - fölbukkanó historizáló elemek megjelenése, amely végeredményben a posztmodern építészetben öltött végső formát. Gondolatilag elszigetelődött a szakmán belül, és ideológiai szemléletében is a perifériára szorult. A marxizmus és a modern építészet örökkévalóságába vetett hite veszett el az 1970-es-1980-as évek változásaival. Major Máté kollégái tiszteletétől és talán kijelenthető: szeretetétől is övezve szinte életének utolsó pillanatáig bejárt a tanszékre. Mindvégig ő maradt a professzor úr. Ha benn volt, szobájának zöldpárnás ajtaja mindig nyitva állt. Az ajtóval csaknem szemközt helyezkedett el a tanártárs, Kaesz Gyula által tervezett íróasztala. Olvasott vagy írt, de mindig szemmel tartotta a szobája előtti mozgásokat. Gyakran behívta az arra járót egy kis beszélgetésre.

\footnotetext{
${ }^{26}$ Példaként említem Hajnóczi Gyula A térszemlélet fejlődése az ókor épitészetében címü kandidátusi diszszertációjáról (1965), hogy annak vélt pozitivista felhangja miatt Mátrai László akadémikus - akit Heller Ágnes nemes egyszerűséggel „opportunista dzsentrinek”, Kenedi János pedig „,a század egyik legcinikusabb magyarjának" nevezett - kategorikusan elutasította annak megjelentetését. Major támogatásával ennek ellenére Hajnóczi megszerezhette a fokozatot és ezzel együtt egyetemi docensi kinevezését.

${ }^{27}$ Major Máté: Nagypanel és tulipán. Élet és Irodalom (1975. szeptember 27.) Ismételten megjelent az írás Major Máté: Nagypanel és tulipán. In: Major Máté - Osskó Judit (szerk.): Új építészet, új társadalom 19451978. (Művészet és elmélet sorozat) Corvina Kiadó, Budapest 1981. 387. Nagy László válasza a kötet 391392., Major viszontválasza a 393-396., míg Nagy László írása a 397. oldalon jelent meg.

${ }^{28}$ Bonta János idézi Tillai megoldásait, nemcsak a TV-képernyőre utaló loggiamegoldást, hanem a paneles lakóház véghomlokzatán megjelenő ablakot centrálperspektívába fogó színezést is. Bonta: i. m. 315.
} 
Érdeklődött a szakma legújabb eseményei felől, tudakolta véleményünket. Minket, fiatalokat igyekezett meggyőzni az organikus gondolat tarthatatlanságáról. Hittel hitte a szocreálon is diadalmaskodó modernizmus győzelmét az újabb „eltévelyedés” a posztmodern fölött. A mai neomodern vagy minimalista tendenciákat látva, talán nem is tekinthető megalapozatlannak az álma.

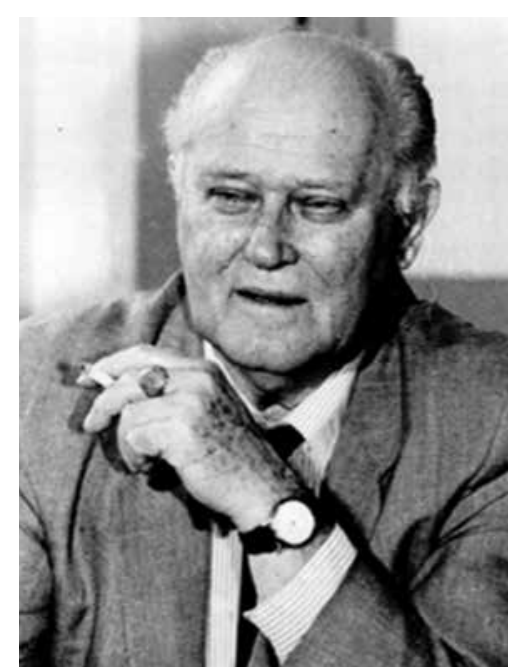

14. ábra. Hajnóczi Gyula

Hajnóczi Gyula (14. ábra) a háború után találta meg élete hivatását. Érettségije után előbb a soproni evangélikus teológia hallgatója lett, majd tanulmányait Pécsett és Kolozsvárott folytatta olasz-müvészettörténet szakon. Hallgatóként kétszer hívták be katonai szolgálatra, végül amerikai fogságból 1945-ben tért haza és 1946 őszén iratkozhatott be az építészkarra. Diplomájának megszerzése után, már 30 évesen Kardos György professzor Újkori Építészettörténet Tanszékén lett tanársegéd. 19541958 között újra beült az iskolapadba, az ELTE BTK ókori régészet-müvészettörténet szakára iratkozott be. Tanulmányainak lezárásaként, már egyetemi adjunktusként 1961-ben szerezte meg bölcsészdoktori címét Térformák és térkapcsolatok az antik római épitészetben c. disszertációjával. A téma egyértelmüen jelzi, hogy érdeklődésének középpontjába az építészeti téralakítás problematikája került, amely végigkísérte egész alkotói pályafutását.

Castiglione László hívására részt vehetett az egyiptomi Nasszer-tó megépítését megelőző núbiai régészeti feltárásokon. Munkája során 1964-ben Abdallah Nirqi régészetileg feltárt, 7 . századi kopt település építészeti felmérési dokumentációját készítette el. Ennek az UNESCO által finanszírozott projektnek a részeként nemzetközi tervpályázatot írtak ki II. Ramszesz fáraó híres sziklatemplomának a megmentése érdekében. A templom a felduzzasztott Nílus vízszintje alá került volna. Hajnóczi 
Pelikán József professzor társával szellemes tervet dolgozott ki a hegybe vájt szentély megemelésére. Elképzelésük helyett egy amerikai terv nyert, amely a szikla feldarabolását javasolta és egy vasbeton héj külső és belső burkolataként állította vissza az ókori emlékhelyet. Különös vonzódása az egyiptomi építészethez ebben az időszakban alakult ki. Gyakran ,panaszkodott”, hogy az ókori építészettörténet előadójaként alig sikerül a mezopotámiai, a hellén és a római építészet bemutatása mellett, az elöre megszabott időkiméretbe sürítenie mondandóját az egyiptomi építészetről. Pedig az ókori építészet kutatójaként a Mediterráneum valamennyi fontos helyszínét személyesen ismerhette meg. Hosszabb ösztöndíjas időszakot tölthetett Itáliában, Irakban is, de megismerte Gallia, Germánia, Raetia és a Noricum antik építészeti emlékeit, régészeti lelőhelyeit is. Nem lehet véletlen, hogy az érettségi utáni útkeresése a teológia után az olasz-müvészettörténet szakra vezette Pécsre, majd Kolozsvárra. Szerette az olasz nyelvet, a latin embereket, az országot. Már nem emlékszem, hogy hány találata volt a totón, de egyetlen nagyobb nyereményét arra használta, hogy újonnan vásárolt Zsigulijával nekiindult Itáliának. Lement Rómába, a Magyar Akadémia akkori igazgatójához a müegyetemi tanártárs Merényi Ferenchez. Feltöltődött ajánlólevelekkel meg élelemmel és elindult Szicíliába. Nem volt elöre eltervezett útiterve, elöre foglalt szállodai szobája. Elment Szicíliát megélni. A görög és a római múltat, a kisvárosok piazzáin borozgató, beszélgető helyieket.

Bölcsész doktorátusának megszerzését követően, alig négy esztendő múltával, 1965 májusában befejezett kandidátusi disszertációjában, az európai építészet további három antik gyökerének téralakítását elemzi a Térszemlélet fejlödése az ókor épitészetében címmel. Mezopotámia, Egyiptom és Hellasz építészeti téralakítását értö szemmel és az alkotás folyamatának ismeretében empátiával volt képes alapvető tudományos eredményeket tézisekbe foglalni. E két dolgozatával sikeresen bizonyította, hogy az általánosan elfogadott építészeti térelmélet felfogásával szemben a tudatos téralakítás kezdetei nem a klasszikus római építészethez kötődnek, hanem már a párhuzamosan fejlődő folyamközi és Nílus-menti civilizációban is érvényesültek a térszerkezetek létrehozásának a szabályai. Mezopotámiában a centrális téralakítás meghatározó jelentőségét ismerte föl, míg Egyiptomban az axiális, a hosszanti tengelyre szervezett térsorozatok alkalmazásában találta meg a kultúrára jellemző térképzés eszköztárát. A gyökerek feltárását és tudományos értékelését követően két írásában tekintette át a térelméleti irodalom 20. századi történetét. Az épitészeti téralakitás értékelése Riegltől Giedionig címü dolgozatot 1967-ben publikálta, míg Az épitészeti tér értelmezése Giediontól Norberg-Schulzig címü írása csaknem az írás megjelenéséig, 1971-ig dolgozta fel a térelméletnek az építészetelméletben általánosan ismertté vált irodalmát.

Közel egy évtizedes előkészület után érett meg Hajnóczi Gyula gondolkodásában az önálló térelmélet megalkotásának a lehetősége. Akadémiai doktori értekezését 1978-ban védte meg Prolegomena az épitészeti alkotás objektiv értékeléséhez; Az épitészeti tér analitikus elmélete ${ }^{29}$ címmel. Vérbeli építészként két dimenzióban,

\footnotetext{
${ }^{29}$ Nyomtatásban először német nyelven jelent meg a dolgozat. Magyarul: Hajnóczi Gyula: Vallum és intervallum. Az épitészeti tér analitikus elmélete. Akadémiai Kiadó, Budapest 1992.
} 
vagyis rajzban szemlélteti a háromdimenziós teret. Kvantitatív analízise tökéletesen érzékelteti a szerkezetfejlödés folyamatát az antikvitástól Corbusier ronchampi kápolnájáig anyaghasználat-téralakítás viszonyában. Megkísérelte ábrázolni az építészeti tér minőségi karakterét is. Kísérletében az épületen belüli térrészletek, a Hajnóczi által tériség fajtáknak nevezett összetevők aprólékos meghatározásáig jutott. A rendszer kezdeti bonyolultságát feloldó, könnyen értelmezhetö és leegyszerüsített rendszer megalkotása már nem adatott meg Hajnóczi Gyulának.

Hajnóczi professzor az építészeti térelmélet mellett a hazai római kori építészeti emlékanyag helyreállítása és bemutatása terén is maradandó életmüvet alkotott. Az antik építészet oktatójaként és a Közel-Keletet megjárt kutatóként és nem utolsósorban okleveles régészként már pályája korai szakaszában bekapcsolódhatott az aquincumi romkert, a Tác mellett feltárt Gorsium-Herculia, Pannónia szakrális központja vagy a fenékpusztai refugium település helyreállításába. Az aquincumi polgárváros bemutatását a főváros az 1960-as évek elején határozta el. A romterület fejlesztési tervének elkészítésével a Budapesti Városépítési Tervező Vállalatot és személy szerint a pályakezdő Vladár Ágnest bízták meg. Hajnóczit konzulensként vonták be a munkába. A fejlesztési tervet még közösen jegyezte Vladár és Hajnóczi, de a tényleges helyreállítás folyamatának a régészeti feltárásokat irányító Póczy Klára mellett már Hajnóczi a vezető tervezője. Példaértékü alapossággal dolgozták ki a bemutatás didaktikus programját. Mindenekelött azt a döntést övezte esetenként éles szakmai vita, amelynek alapján a Kr. u. 2. és 3. századi emlékanyag bemutatását tekintették megvalósíthatónak. A gyenge minőségü és gyakorlatilag értelmezhetetlen 1. és 4. századi maradványokat nem tartották meg. A didaktikus döntés értelmében a 2. századból származó épületmaradványok falait csak alaprajzban, a kialakított padló szintjében érzékeltették, míg a későbbi, 3. századi periódust, szükség és értelmezhetőség szerint „megemelték”, s így mutatják meg a nagyközönségnek a római kori falakat. A kor íratlan szabályaival ellentétesen, de később a Velencei Karta írott ajánlásaival is szembe kerülve, három emléket a 3. dimenzióban is érzékeltetni kívántak. A Forum nyugati sarkának ,megemelése” (15. ábra) és a Collegium Iuventutis peristylium oszlopainak felállítása (16. ábra) a szakma ítészeinek ingerküszöbét még nem lépte át. A húspiac ${ }^{30}$ kis centrális mérlegházának (17. ábra) megemelése és a megtalált fél oszlopoknak a falazaton történő bemutatása csaknem az egész program megvalósítását tette lehetetlenné. Hosszas küzdelem eredményeként sikerült az eltervezett épülettorzót a tervező által elképzelt állapotában bemutatni. Aquincumban alkalmazták először az ún. didaktikus csíkot, ami az eredeti falazatot volt hivatott elválasztani a szükségszerü modern ráfalazásoktól. Hasonlóan Póczy Klárától és Hajnóczi Gyulától származó eredeti didaktikus ötlet a római kori helyiségek épületen belüli helyzetének egységes értelmezése és bemutatása. Így születhetett meg a belső tereknek vörös salakkal történt burkolása. Az oszlopcsarnokok, mint félkülső terek, fehér murvaborítást kaptak, míg a külső terek, akár udvarok vagy utcák is lehettek,

\footnotetext{
${ }^{30}$ A Macellum peristil udvarának közepén álló, kör alaprajzú mérlegház megemelése a 3. dimenzióban elfogadhatatlan volt az újonnan elfogadott Velencei Karta bűvöletében élő hivatali vezetők számára.
} 


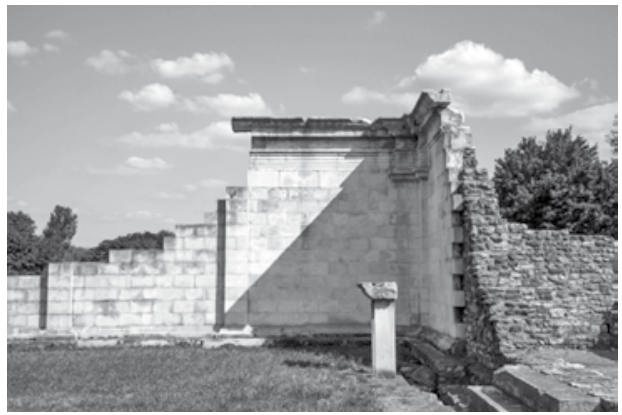

15. ábra. Aquincum, polgárvárosi fórum nyugati fala

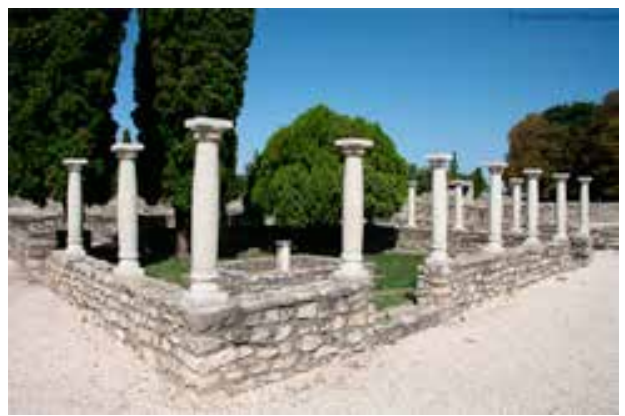

16. ábra. Aquincum-polgárváros, Collegium Iuventutis helyreállított oszlopsora

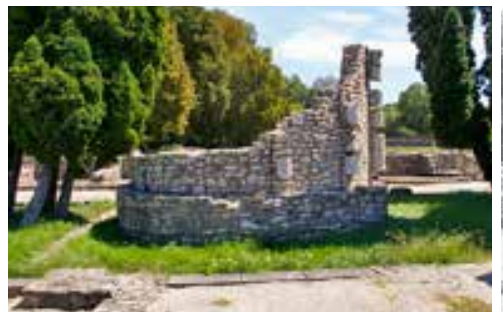

17. ábra. Aquincum-polgárváros, halpiac, (macellum) mérlegház

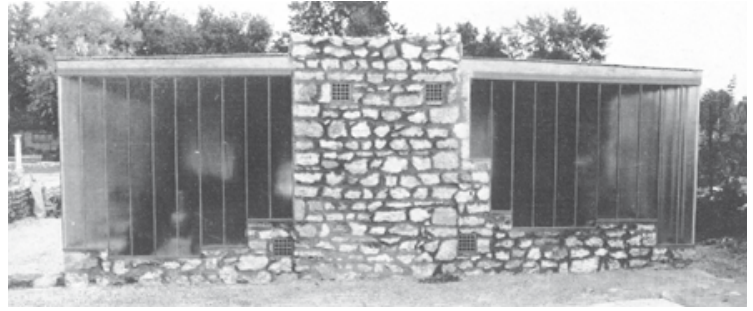

18. ábra. Aquincum-polgárváros, a Birkózókat ábrázoló mozaik védőépülete

gyepesítve készültek el. Új és a kor szabályait is betartó védőépületek is születtek a 10 éves program keretében. A Dirke bünhődését és a Birkózókat ábrázoló (18. ábra) mozaikok védelmére az eredeti falazatot felhasználva falpilléreket emelt Hajnóczi, amelyre vasbeton lemez került. Az így kialakított teret a kor divatos szerkezetével, kopolit üvegfallal zárta körbe.

Hajnóczi Gyula emblematikus alkotása volt a szombathelyi Iseum bemutatása. A vasbeton „tartószerkezet” szolgált az eredeti márvány faragványok és épülettagozatok installációjaként (19. ábra). A modern építészet szellemének tökéletes megjelenítése volt a mü - Hajnóczi megfogalmazása szerint „quasi anastylozisz” -, melyet a müemlékvédők velencei konferenciáján 1964-ben, mint az akkor elfogadott Karta első megvalósulása példájaként ünnepeltek a konferencia résztvevői.

Hajnóczi professzor számára a maradandó építészetelméleti gondolatoknál, a nagyszerủ római kori helyreállításoknál többet jelentett a Mủegyetem, a hallgatók közelsége, szeretete, a tanítás maga. Lelkes technikai újítóként számtalan oktatástechnikai ötlet származott tőle. Ezekkel is az anyag megértéséhez, elsajátításához kívánt segítséget nyújtani. Az elődöktől átvett szellemiség, mindenekelőtt a haláláig tisztelt professzor, Rados Jenő tanár úr példáját követve, hosszú évek kihagyása után Hajnóczi szervezte meg ismételten a felmérési gyakorlatoknak a tananyagba illesztését. Előbb Aquincumban hozta létre az építészhallgatók nemzetközi régészeti ásató táborát, ami- 


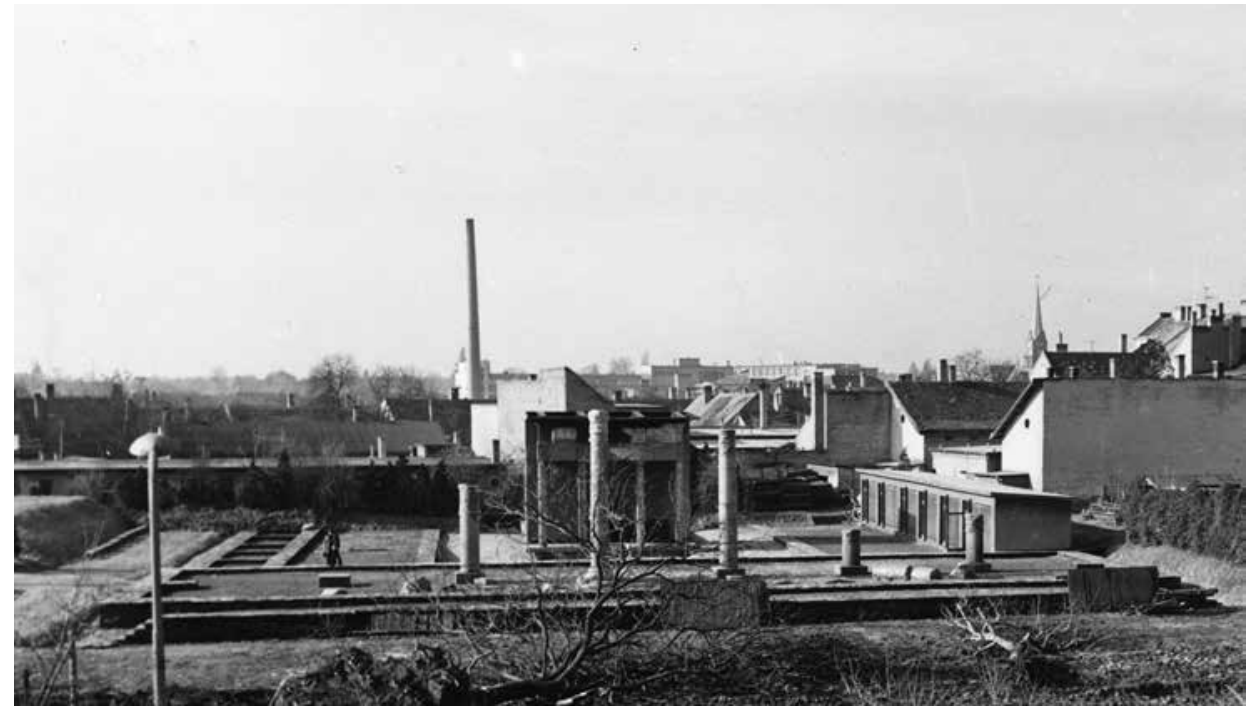

19. ábra. A szombathelyi Iseum quasi anastylosisa 1964-ben

re mind a mai napig lelkesen emlékeznek az egykori táborlakók. Sebő Ferenctől Rajk Lászlóig, Fejérdy Tamásig hosszú a hazai résztvevők névsora. Majd az 1980-as évektől a 120 fós évfolyam számára szervezett történeti városfelmérések sora következett. Így tölthettek felejthetetlen két hetet a másodévesek Baján is 1981 nyarán.

Hajnóczi tanár úrral közelebbi kapcsolatba csak azután kerülhettem, hogy 1983ban elfogadott aspiránsának, és befogadott a nem túl nagyméretü professzori szobájába is. Kapcsolatunk a haláláig tartó 13 évben viszont annál intenzívebb volt. Hetente járhattam vele Aquincumba a polgárváros egyes, még bemutatásra váró épületeinek felmérésére. Hallgathattam beszélgetését a tisztelt és szeretett munkatárs, Póczy Klára régésszel, ahol az egyes építési periódusok értelmezésének-bemutatásának problémáit vitatták meg. Élvezettel figyeltem rekonstrukciós elképzelései fölvázolásának a folyamatát. Amint a régészek által feltárt faltöredékek felmérési rajzai nyomán - a nem ritkán az egyszerre égő két cigaretta füstfelhőjéből - kibontakoztak az építészetileg és szerkezetileg is logikus térkapcsolatok, majd az épületet lefedő tető megépíthetően tiszta konstrukciója. Első közös munkánk, ahol érdemi feladatot bízott rám, a tatai várban megépített, Brigetióból származó „Római szoba” falképeinek elhelyezésére szolgáló tartószerkezet megtervezése volt (20. ábra). A munka megkezdésekor Bíró Endre régész még az egyik malom padlásán javában a festett vakolattöredékek összeillesztését, a falkép rekonstrukciójának fáradságos és időigényes munkáját végezte. ${ }^{31} \mathrm{~A}$ feladat nehézségét az jelentette, hogy a boltozott terem egykori

\footnotetext{
${ }^{31}$ A bemutatott római kori szobáról részletesen tájékoztat a tatai Vármúzeum kiállításvezető füzete: II. századi falfestmény Brigetióból. Kiállításvezető a tatai Kuny Domokos múzeum állandó kiállításához II. A kiállítást rendezte és a vezetőt írta Bíró Endre. Restaurálás ifj. Bóna István és Móré Miklós. Tata, Vár 2001.
} 


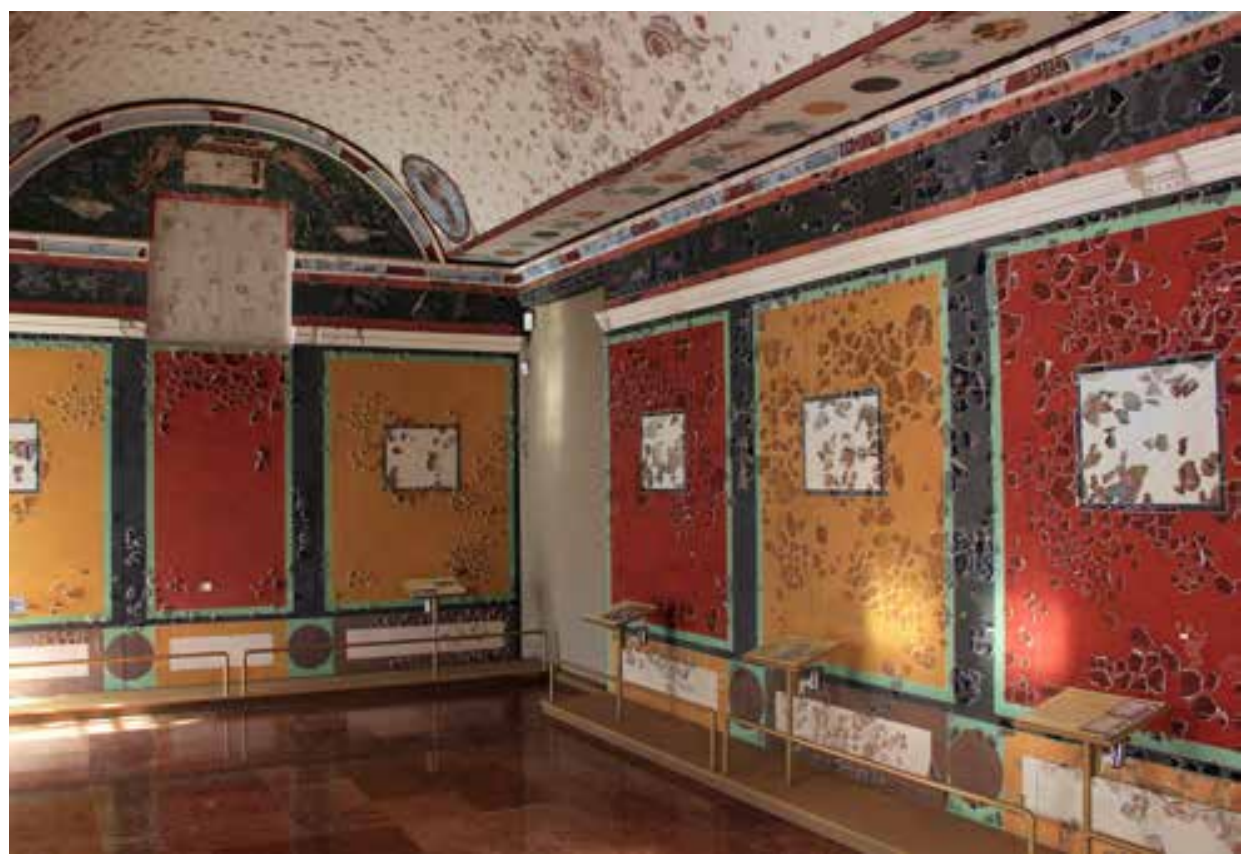

20. ábra. A Brigetióban feltárt falfestményes római szoba bemutatása a tatai várban

lefedését felfüggesztő szerkezet nem csupán az egyes vakolatdarabok rögzítésére szolgált, hanem a restaurátor, ifj. Bóna István által megrajzolt és megfestett visszafogott rekonstrukció didaktikus bemutatását is be kellett fogadnia. Emlékeim szerint Bíró Endre is ahhoz a korosztályhoz tartozott, akik évfolyamtársai voltak a régészetet tanuló Hajnóczinak, akit a régész szakmában egyszerüen „Födém”-nek hívtak, nem csak a bölcsészkaron. A becenév onnan származott, hogy Oroszlán Zoltán, a szak nagy tekintélyủ régészprofesszora felkérte a fiatal építészt a római kori építészetet bemutató előadások megtartására. A mondandó során gyakran ismételt födém kifejezés a bölcsészhallgatók számára nem volt ismert, de miért, miért nem, megkérdezni sem merték ezt a náluk csaknem 10 évvel idősebb évfolyamtárs előadótól. Viszont a név Hajnóczin ragadt! Évtizedekkel később, egyik bajai látogatásunk során Kőhegyi direktor úr, a Türr István Múzeum igazgatója és Hajnóczi egykori évfolyamtársa is még ezen a néven szólította kedves barátját.

Az együtt töltött bő évtized során szinte végigjártuk az 1960-as évek nagy római kori helyreállítási programjainak helyszíneit. Volt, ahol csak anyaggyüjtés volt a cél a Pannónia római romjai ${ }^{32}$ címü kötetéhez. Évekkel később szerette volna kibővítve újra kiadni a népszerüvé lett könyvet, de akkor a Müszaki Kiadó már nem a számára megszokott feltételekkel dolgozott. Így egy római kori emlékeket bemu-

\footnotetext{
${ }^{32}$ Hajnóczi J. Gyula: Pannónia római romjai. Müszaki Könyvkiadó, Budapest 1987.
} 
tató, négy nyelven publikált útikönyvet állított össze a hazai római koros régész szakma közremüködésével. ${ }^{33}$ Persze újabb és újabb feladatok megoldására is hívták, és boldogan mentem vele. Gorsiumban Fitz Jenőnek készíthettük el az egykori település bemutatásának távlati fejlesztési tervét. Ennek megvalósításán ma már sajnos csak egyedül kell dolgoznom. Gyakran megfordultunk a Veszprém közeli Baláca pusztán, a sok problémával küzdő villaépület hibáinak kijavítása (21. ábra) és a Likas-dombnak nevezett halomsír bemutatásának (22. ábra) tervezése miatt. Kővágószőlős egykori mauzóleumának védelmét a Mecseki Uránbánya Vállalat megbízásából és kivitelezésében készítette el. A maga idejében izgalmas cella memoriae bemutatása a bánya bezárása után a vandálok pusztításának vált áldozatává (23. ábra). Fenékpusztán Müller Róbertnek, a Balaton Múzeum igazgatójának hívására készítettünk programot a refugium település életre keltése érdekében (24. ábra). Dunafüreden a fürdő fölé emelt védőépület megújítására összeállított vázlatok - Poroszlay Ildikó váratlan halála miatt - a soha meg nem valósult tervek sorát

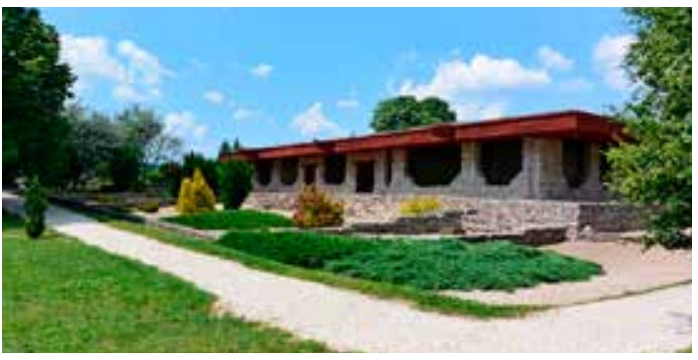

21. ábra. Baláca, villagazdaság, I. épület

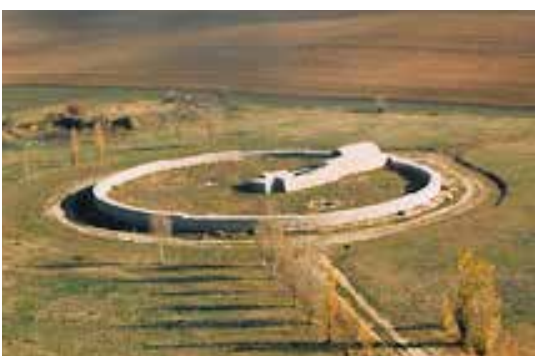

22. ábra. Baláca, Likas-domb - tumulus bemutatása

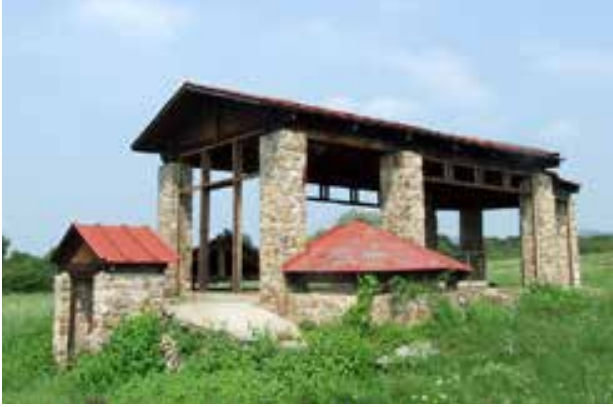

23. ábra. Kővágószőlős, az egykori helyreállítás látványa napjainkban

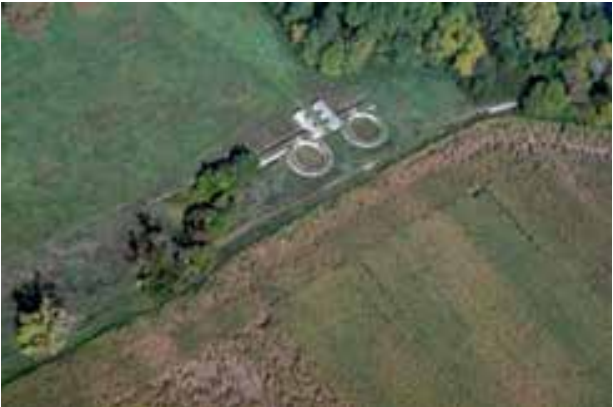

24. ábra. Fenékpuszta, a refugium település bejárati kaputornyainak részleges rekonstrukciója

${ }^{33}$ Itinerarium Hungaricum I. - Pannonia Hungarica Antiqua (szerk.: Hajnóczi J. Gyula, Mezős Tamás, Nagy Mihály, Visy Zsolt). Archaeolingua Kiadó, Budapest 1995. (magyarul és olaszul), 1998. (angolul és németül). 
gyarapítják. Visegrád közelében, a Gizella-majorban a Gróh Dániel és Gróf Péter régészek által feltárt nagyszerü római kori kiserőd romjai fölé is készült egy védőtető terve a védelem megvalósítására.

Haláláig szerette és tisztelte a principálisának nevezett Rados Jenő professzort. Meghatározó élménye volt a Rados irányításával elkészített felmérés a fertődi Esterházy-kastélyban, Esztergomban vagy Székesfehérváron. Nem lehetett hosszú időn át közvetlen munkatársa Jenő bácsinak, hiszen mesterét '56-os „,szerepléséért” eltávolították az egyetemről. Ennek ellenére rendszeresen találkoztak a VÁTI-ban nyugdíjasként dolgozó „Öreggel”. Rados magyar építészettörténete ${ }^{34}$ pannóniai fejezetének megírására az egykori kedves tanítványt és munkatársat kérte föl. A tisztelt tanárra és kollégára emlékezve, Rados halála után emlékkönyv összeállítását szervezte. Nem a hagyományos, tudományos dolgozatok megírására kérte föl kollégáit-barátait. A Rados Jenö legendája címü kis kötetbe olyan visszaemlékezések kerültek, amelyek elsősorban Radosra jellemzően a humort, az élet fonákságainak kifigurázását füzték csokorba. Ô maga írta le az esetet, amikor fogadást kötött kollégáival, Nagy Elemérrel és Ferenczy Károllyal, hogy megsimogatja az „öreg” mindig fényesre borotvált koponyáját. Megnyerte a fogadást.

Hajnóczi diplomájának megszerzése után nem a Rados által vezetett középkori, hanem a Kardos György irányítása alatt álló Újkori Építészettörténet Tanszékre került. Kardos maga is nagyszerüen rajzolt, és tudatosan választotta ki azokat a fiatalokat, akik szintén hibátlanul „beszélték” az építészet közös nyelvét, a rajzot. Talán még hallgató korában kapta Kardos tanár úrtól a megbízást, hogy szeretett Vízivárosának gyöngyszemét, a Batthyányi téri Szent Anna-templomot több nézetből, lehetőség szerint a környező háztetők magasából rajzolja le. Nagy veszély fenyegette abban az időben a budai templomokat. Rákosi ugyanis kitalálta, hogy mi lesz, ha Sztálin elvtárs meglátogatja őt az Akadémia utcai pártközpontban és az ablakon kitekintve, a panorámában gyönyörködve bizonyára rossz néven venné majd, ha több templom tornya „zavarná” a kilátást. Nem volt akkor még eldöntött tény, hogy a Szent Anna- vagy a Szent Erzsébet-templom esik-e áldozatul az ostobaságnak, de Hajnóczi a megbízást sikeresen és színvonalasan teljesítette. Élete végéig emlegette egyik első akadémiai kitüntetését is. A város eklektikus kovácsoltvas emlékeiről készített rajzsorozatával nyert megtisztelő jutalmat.

A háború és az amerikai fogság után (a bajorországi Bad Aiblingben hidat épített), amikor beiratkozott az építészkarra, a Fő utca 77-ben kapott albérleti szobát. Annyira szerette a Duna-partra néző földszinti lakást, hogy miután megházasodott és elnyerte egyetemi állását, társbérletben egykori szállásadójánál maradtak. Dolgozószobája, az egykori albérleti szoba évtizedekig szolgálta az elmélyült alkotó-kutató munkát. Ebéd utáni „slumizása” és a rövid Duna-parti séta után kezdődött itt az éjszakába nyúló „második müszak”. Szerette a Dunát, minden nap, különösen élete vége felé

\footnotetext{
${ }^{34} \mathrm{~A}$ kötet „Építészetünk elözményei Magyarország területén” c. I. fejezetének címéhez Rados a következő megjegyzést füzte: „E fejezet anyagát Hajnóczi Gyula kutatásainak, gyüjtésének és összeállitásának felhasználásával közlöm.” Rados Jenő: Magyar épitészettörténet. Müszaki Könyvkiadó, Budapest 1961. 11.
} 
visszavitte a folyó az evezéssel, úszással eltöltött ifjú korba. Emlékei közül néhányat megírt. Remélte, hogy Major Mátéhoz hasonlóan, ő is kiadathatja visszaemlékezéseinek kötetét. Az Alföld címü kecskeméti irodalmi lapnál próbálkozott, de végül nem közölték az írásokat. A nagy nyilvánosság számára a gimnazista Hajma bajai történetei végül a Bajai Hírmondóban jelenhettek meg.

Szívszorító volt a búcsú az alma matertől. 1996 nyarán én vittem be a budai Szent Imre Kórházba. Már nehezen kommunikált, de határozottan kért, hogy menjünk az Egyetemhez. A Központi épület főbejárata elé kanyarodva, megálltam. Gyuszi bácsi percekig némán simogatta tekintetével a sokszor koptatott bejáratot, a nehéz, rézborítású kaput, a fényesre csiszolódott kilincset. Ez a néhány perc volt számára a búcsú, nemcsak a szeretett Müegyetemtől, hanem talán már az élettől is.

\title{
THREE KOSSUTH PRIZE LAUREATE ARCHITECTS, BORN IN BAJA
}

\begin{abstract}
Summary
Three young men were born with an interval of two decades in the town of Baja, who, after graduating from high school, first became the students of the Architecture Class, then, that of the Faculty of Architecture at the Royal Hungarian József Nádor Technical University of Budapest. All three of them were honored by the most prestigious state order, the Kossuth Prize. Máté Major and Gyula Hajnóczi became the professors of the Faculty and the members of the Hungarian Academy of Sciences. László Miskolczy, the senior in age, became a prominent figure of national architecture as a practicing designer. While the careers of Major and Hajnóczi were closely related to the University of Technology - teaching history of architecture -, Miskolczy emigrated to the United States in 1956, a couple of months later, he was granted by the honor. He achieved success as a structural designer in his new, chosen country.

This study intends to commemorate the architects who all set off from a provincial intellectual middle-class family background and received the most prestigious Hungarian recognition. The year 2020 will mark the $120^{\text {th }}$ anniversary of Miskolczy's and the $100^{\text {th }}$ anniversary of Hajnóczi's birth. The research into anniversaries showed that Major was elected a corresponding member of the Hungarian Academy of Sciences 70 years ago, in 1949 .

László Miskolczy's lifework at home could be partially reconstructed by the traceable data, according to the elegant World War I. memorial in Baja, the Navy memorial, or the materialized designs of some apartment blocks, residential and public buildings. In terms of Miskolczy, the zenith of his life was the hospital of Mátraháza, due to its organic connections.

The end of professor Máté Major's career as an architect-engineer was marked by designing the outstanding worker houses in Tatabánya, 1949. His policy-making activity between the two wars fully realized its purpose only after he was promoted and became a university professor. His lifework in architecture theory found response both in the national and in the international scientific literature.

The name of Gyula Hajnóczi became renowned as a European researcher and restorer of ancient architecture. He was participating in almost every piece of Roman monument revitalization project acting as the designer of presenting and constructing the Aquincum Archeological Park. His oeuvre in
\end{abstract}


architecture theory remains unfinished in creating an introduction to a unique spatial theory in architecture, but his thoughts supported his followers' cast of minds when understanding the concept of space.

Keywords: László Miskolczy, Máté Major, Gyula Hajnóczi, Kossuth-prize laureate architects, born in Baja

Open Access nyilatkozat: A cikk a Creative Commons Attribution 4.0 International License (https://creativecommons.org/licenses/by/4.0) feltételei szerint publikált Open Access közlemény, melynek szellemében a cikk bármilyen médiumban szabadon felhasználható, megosztható és újraközölhető, feltéve, hogy az eredeti szerző és a közlés helye, illetve a CC License linkje és az esetlegesen végrehajtott módosítások feltüntetésre kerülnek. (SID_1)

๑ Beérkezett: 2017. március 9. Elfogadva: 2017. március 28. 